\title{
Keberadaan Mikoriza Arbuskular pada Lokasi Pertanaman Jarak Pagar (Jatropha curcas L.) di Lembah Palu
}

\section{The Existence Indigenous Arbuscular Mycorrhizal Fungi at Jatropha curcas L. in Palu Valley}

\author{
Iskandar Lapanjang \\ Fakultas Pertanian, Universitas Tadulako, INDONESIA \\ *corresponding author, email: sikandarlapanjang@ymail.com
}

Manuscript received: 20-05-2019. Accepted: 17-06-2019

\begin{abstract}
ABSTRAK
Setiap rhizosfir suatu tanaman pada suatu ekosistem memiliki berbagai jenis mikroorganisme termasuk FMA. Masing-masing tipe ekosistem memiliki jenis dan kepadatan FMA yang beragam demikian halnya dengan potensinya. Penelitian ini bertujuan untuk mengetahui keberadaan dan potensi sumberdaya fungi mikoriza arbuskular indigenous di lokasi penanaman jarak pagar pada lahan kering pegunungan di Lembah Palu di daerah Poboya, Palu, Propinsi Sulawesi Tengah. Kegiatan penelitian ini diawali dengan pengambilan sampel tanah pada ekosistem tersebut, yang kemudian diamati dengan mikroskop. Selanjutnya dilakukan penghitungan propagul dengan metode Most Probable Number (MPN), trapping spora, identifikasi jenis spora dan kultur tunggal. Hasil studi menunjukkan bahwa jumlah propagul infektif FMA dari kebun dan tanah alami berturut-turut sebesar 1117 dan 711 mikroorganisme/g tanah; dan FMA indigeneous asal tanah pertanaman tanaman jarak pagar didominasi oleh Glomus sp).
\end{abstract}

Kata kunci: Glomus sp.; trapping; most probable number

\begin{abstract}
Plant rhizosphere has various types of microorganisms, including Arbuscular Mycorrhizae Fungi (AMF). Each ecosystem has different species and densities of AMF. For further use, study the potency of indigenous AMF is necessary. This research was conducted to know the existence and potency of indigenous AMF of soil where physic nuts grow on dry land of Palu Valley at Poboya, Palu, Central Sulawesi. Soil samples were collected, and then observed under microscope. The steps to study the potency of AMF were counting the propagules with Most Probable Number (MPN) method, spora trapping, identifying the types of spore, and single spore culture. The result showed that the number of infective AMF propagules from cultivated soil was 1117 microorganisms/g soil and from of natural soil was 711 microorganisms/g soil; and indigenous AMF from the soil where physic nut grown at Lembah Palu were dominated by Glomus sp.
\end{abstract}

Keyword: Glomus sp.; trapping; most probable number. 


\section{PENDAHULUAN}

Keberhasilan pengembangan tanaman jarak pagar di suatu wilayah, dapat diduga dengan mengetahui potensi wilayah tersebut baik potensi fisik, kimiawi maupun biologinya, walaupun tidak dapat dipungkiri bahwa seperti yang dikatakan Santoso (2009) bahwa eksplorasi teknologi budidaya tanaman jarak pagar sangat penting sehubungan dengan pengembangan tanaman ini sebagai sumber energi terbarukan yang tahan terhadap kekeringan. Sifat tahan kekeringan tersebut dapat dikarenakan karakter genetis-fisiologis tanaman dan juga karena adanya simbiosis dengan organisme lainnya sebagai suatu menghuni di suatu habitat.

Keterkaitan dengan interaksi dengan organisme lain dalam lingkungan tumbuhnya, maka salah satu potensi biologi alamiah yang dapat digunakan untuk meningkatkan keberhasilan pengembangan tanaman jarak pagar adalah potensi simbiosis tanaman jarak pagar dengan fungi mikoriza arbuskular (FMA). Walaupun pemanfaatan FMA guna meningkatkan keberhasilan budidaya tanaman telah banyak dilakukan, tetapi informasi potensi FMA indigenous yang spesifik di tanah kering pada lahan pertanaman jarak pagar belum banyak terungkap.

Keberadaan propagul dapat digunakan sebagai indikator potensi FMA pada suatu lahan. Karena FMA mengkolonisasi tanaman inangnya dengan propagul (spora, hifa, akar terinfeksi FMA). Beberapa hasil penelitian menunjukkan bahwa setiap jenis tanah dan jenis tanaman memiliki jenis dan kepadatan FMA, serta jumlah propagul infektif yang berbeda. Keberadaan propagul infektif dan perkiraan populasi FMA indegenous diperlukan berkaitan dengan pemanfaatannya sebagai inokulum pada budidaya tanaman pada suatu kawasan. Metode Most Probable Number $(M P N)$ dapat digunakan untuk menghitung jumlah propagul infektif dan memperkirakan populasi FMA (Sieverding, 1991). Pendapat ini sesuai dengan Porter (1979) bahwa MPN merupakan metode untuk memperkirakan jumlah organisme mikroba dengan pengenceran yang kemudian diadopsi dan dikembangkan untuk kepentingan percobaan menggunakan FMA.

Keanekaragaman FMA pada lahan kering di Indonesia cukup tinggi. Hal ini disebabkan karena Indonesia memiliki keanekaragaman tanaman, yang dapat dijadikan inang FMA. Menurut Kramadibrata dan Hedger (1990), pada tanaman kakao di pulau Jawa dan Bali ditemukan FMA genus Acaulospora walkeri, sedangkan hasil penelitian Kartika (2006) menunjukkan bahwa FMA pada tanah jenis PMK bekas hutan, dan PMK bekas kebun karet, serta gambut bekas hutan memiliki jumlah dan keragaman FMA yang berbeda. Selanjutnya Swasono (2006) menunjukkan bahwa pada lahan lokasi pantai Samas Kabupaten Bantul Propinsi Daerah Istimewa Yogyakarta terdapat tiga macam FMA yaitu Glomus sp-1, Glomus $s p-2$ dan Gigaspora sp. Ketiga FMA tersebut bersimbiosis dengan tanaman Tridax procumbens. Di daerah pengembangan jarak pagar di Desa Poboya, Kota Palu, Propinsi Sulawesi Tengah, merupakan lahan kering pegunungan. Lahan kering

pegunungan memiliki karakteristik lingkungan (tanah dan tanaman) yang khas, sehingga kemungkinan memiliki kepadatan spora dan jenis FMA atau propagul infektif yang khas dan belum ada yang mengungkap. Artikel ini memaparkan hasil penelitian yang bertujuan untuk mengetahui potensi sumberdaya FMA di lokasi pertanaman jarak pagar Desa Poboya, Kotamadya Palu, Propinsi Sulawesi Tengah yang merupakan lahan kering pegunungan. 


\section{BAHAN DAN METODE}

Tempat, waktu, dan bahan penelitian

Penelitian dilaksanakan di rumah kaca dan Laboratorium Silvikultur Fakultas Kehutanan IPB pada bulan November 2008 sampai dengan Agustus 2009. Bahan utama yang digunakan adalah propagul dari daerah penanaman jarak pagar. Propagul yang diambil berupa tanah sampel dan akar tanaman yang mengandung mikoriza, yang diambil dari daerah perakaran tanaman jarak pagar.

\section{Metode Percobaan}

Pengambilan Contoh Tanah. Pengambilan contoh tanah dilakukan di lokasi pertanaman jarak pagar di Propinsi Sulawesi Tengah yaitu dari ekosistem kebun campuran (lahan dimana tanaman jarak dibudidayakan berdekatan dengan tanaman jagung, kacangkacangan, dll) dan ekosistem bukan kebun (lahan dimana tanaman jarak tumbuh sendiri secara alami) pada daerah pegunungan di desa Poboya. Contoh tanah diambil dari zona perakaran jarak pagar pada kedalaman 5-20 cm, kemudian dimasukkan ke dalam kantong plastik dan diberi label. Contoh tanah merupakan komposit dari 20 titik pengambilan contoh, dimana masing-masing titik banyaknya $250 \mathrm{~g}$.

Pengamatan Spora Awal. Pengamatan spora awal dilakukan di bawah mikroskop. Ekstraksi FMA

dilakukan untuk memisahkan spora dari contoh tanah sehingga dapat diamati keberadaan spora FMA. Teknik yang digunakan adalah teknik tuang-saring dari Pacioni (1992) dan dilanjutkan dengan teknik sentrifugasi dari Brundrett et al. (1996). Prosedur teknik tuang-saring ini adalah contoh tanah sebanyak $50 \mathrm{~g}$ ditambah dengan 200-300 ml air, lalu diaduk sampai butiranbutiran tanah hancur, kemudian didiamkan selama \pm 2-5 menit. Selanjutnya larutan disaring dalam satu set saringan dengan ukuran $500 \mu \mathrm{m}, 250 \mu \mathrm{m}, 125 \mu \mathrm{m}$, dan $63 \mu \mathrm{m}$, secara berurutan dari atas ke bawah. Saringan bagian atas (saringan $500 \mu \mathrm{m}$ ) disemprot dengan air kran untuk memudahkan spora lolos, kemudian saringan teratas dilepas, dan sejumlah tanah sisa yang tertinggal pada saringan terbawah dipindahkan ke dalam tabung sentrifuse.

Isolasi spora teknik tuang-saring ini kemudian diikuti dengan teknik sentrifuse dari Brundrett et al. (1996). Hasil saringan dalam tabung sentrifuse ditambah glukosa sebanyak 60 $\%$ dengan menggunakan pipet. Tabung sentrifuse ditutup rapat dan disentrifuse dengan kecepatan 2500 rpm selama 3 menit. Selanjutnya larutan supernatan tersebut dihisap dengan pipet hisap dan dituangkan ke dalam saringan $45 \mu \mathrm{m}$, dicuci dengan air mengalir (air kran) untuk menghilangkan glukosa. Endapan yang tersisa dalam saringan di atas dituangkan ke dalam cawan petri plastik dan kemudian diperiksa di bawah mikroskop binokuler untuk mengamati keberadaan dan jumlah spora. Selain adanya spora kemungkinan ada propagul lain sehingga dilakukan juga penaksiran jumlah propagul dengan teknik Most Probable Number $(M P N)$.

Penaksiran Kepadatan Propagul dengan Teknik MPN. Setiap contoh tanah (tanah yang diambil dari lapangan) dihaluskan dan dilakukan pengenceran dengan kelipatan 10 sebanyak 8 
kali pengenceran, dengan mencampur contoh tanah yang langsung dari lapangan dengan zeolit yang telah steril. Setiap pengenceran diulang lima kali, kemudian campuran media dimasukkan ke dalam pot-pot plastik. Prosedur penghitungan $M P N$ dilakukan dengan menggunakan metode Sieverding (1991). Benih Pueraria javanica yang telah disterilkan dan telah dikecambahkan ditanam pada pot kultur tersebut, dipelihara di rumah kaca selama lebih kurang 5 minggu. Pemeliharaan meliputi penyiraman dan pemupukan dengan larutan hara Hyponex merah (255-20). Setelah 5 minggu, dilakukan pemanenan akar dengan cara memotong bagian akar. Akarakar tersebut dicuci dan dipotong-potong kemudian dimasukkan ke dalam botol yang berisi Formaline Aceto Alcohol (FAA). Selanjutnya akar-akar tersebut diwarnai dengan larutan pewarna melalui teknik pewarnaan akar dari Kormaik dan Mc.Graw (1982). Akar-akar yang telah diberi larutan pewarna (destaining) diamati di bawah mikroskop untuk melihat ada tidaknya infeksi FMA. Prosedur lengkap pewarnaan akar dapat dilihat pada

Trapping (Pemerangkapan) FMA. Teknik trapping yang digunakan mengikuti metode Brundrett et al. (1996) dengan menggunakan pot-pot kultur kecil. Media tanam yang digunakan berupa campuran contoh tanah sebanyak $\pm 50 \mathrm{~g}$ dan batuan zeolit berukuran 1-2 mm sebanyak \pm 125 g. Contoh tanah terdiri atas dua macam yaitu; (1) tanah asal kebun dari Desa Poboya (Pk) dan (2) tanah asal bukan kebun dari Desa Poboya (Pbk) masing-masing diulang enam kali, sehingga total satuan percobaan adalah 12. Teknik pengisian media tanam dalam pot adalah pot kultur diisi dengan zeolite sampai setengah volume pot, kemudian dimasukkan contoh tanah dan terakhir ditutup dengan zeolit sehingga media tanam tersusun atas zeolit-contoh tanahzeolit.

Benih-benih Pueraria javanica yang akan digunakan sebagai tanaman inang terlebih dahulu direndam dengan klorox $5 \%$ selama 5-10 menit sebagai upaya sterilisasi permukaan, kemudian dicuci sampai bersih dengan air mengalir. Setelah itu benih direndam dengan air panas selama \pm 3 menit, kemudian direndam dengan air dingin selma 24 jam. Perendaman benih tersebut adalah suatu upaya untuk memecahkan dormansi. Selanjutnya benih dikecambahkan selama satu minggu atau sampai muncul 2 helai daun. Setelah itu kecambah dipindahkan langsung ke dalam pot-pot kultur.

Pemeliharaan kultur meliputi penyiraman, pemberian hara dan pengendalian hama secara manual. Larutan hara yang digunakan adalah Hyponex merah (25-5-20) dengan konsentrasi $0.5 \mathrm{~g} / \mathrm{l}$ air. Pemberian larutan hara dilakukan setiap minggu sebanyak $20 \mathrm{ml}$ tiap pot kultur. Setelah kultur berumur \pm empat bulan dilakukan pemanenan untuk mendapatkan spora-spora yang akan digunakan pada kegiatan tahap berikutnya. Peubah yang diamati adalah jumlah spora per 50 g media tanam dan tipe spora.

Isolasi Spora dan Identifikasi FMA. Ekstraksi FMA dilakukan untuk memisahkan spora dari contoh tanah sehingga dapat dilakukan identifikasi FMA guna mengetahui genus spora FMA. Teknik yang digunakan adalah teknik tuang-saring dari Pacioni (1992) dan dilanjutkan dengan teknik sentrifugasi dari Brundrett et al. (1996) sama dengan teknik pengamatan awal. Endapan yang tersisa dalam saringan setelah pencucian terakhir, dituangkan ke dalam cawan petri 
plastik dan kemudian diperiksa di bawah mikroskop binokuler untuk penghitungan spora dan pembuatan preparat guna identifikasi spora FMA.

Preparat spora disiapkan dengan bahan pewarna Melzer's dan bahan pengawet PVLG yang diletakkan secara terpisah pada satu kaca preparat. Spora FMA yang diperoleh dari ekstraksi setelah dihitung jumlahnya diletakkan dalam larutan Melzer's dan PVLG. Selanjutnya sporaspora tersebut dipecahkan secara hati-hati dengan cara menekan kaca penutup preparat menggunakan ujung lidi. Identifikasi spora dilakukan menurut metode Schenck dan Perez (1990) dan Brundrett et al. (1996).

Pembuatan Kultur Spora Tunggal. Kultur tunggal dengan dibuat pot-pot kultur kecil berupa gelas plastic berwarna yang sebelumnya telah dilubangi di bawahnya dan dilapisi lagi dengan gelas plastik yang tidak dilubangi, berfungsi sebagai tempat air bagi kultur. Kemudian pot-pot plastik diisi batuan zeolit berukuran 1-2 mm sampai penuh dan cukup padat. Sebelumnya zeolit disterilisasi dengan autoklaf untuk mematikan patogen atau nematoda yang terbawa yang dapat merusak kultur. Spora-spora FMA yang telah diisolasi dari kultur trapping dikumpulkan dalam gelas arloji dan dilakukan pemisahan berdasarkan genusnya. Bibit $P$ javanica yang telah memiliki 2-3 helai daun (umur 7-10 hari setelah semai) diletakkan di atas kertas putih atau kertas tissue, selanjutnya spora diambil dengan pinset dan diletakkan pada akar bibit tersebut. Setiap bibit hanya diinokulasi dengan satu spora. Bibit yang telah diinokulasi dipindahkan ke pot plastik, kemudian diberi label. Pot selanjutnya diletakkan pada rak-rak di rumah plastik. Kultur dipelihara selama 6 bulan tergantung sporulasi yang terjadi. Perkembangan proses sporulasi dalam setiap kultur diamati setiap minggu yang dimulai pada awal minggu kedua setelah pembuatan kultur. Jika spora yang terbentuk sudah cukup banyak, dilakukan sub-kultur ke dalam pot-pot yang lebih besar.

Perbanyakan Kultur FMA. Kultur spora tunggal yang sudah menghasilkan spora cukup baik langsung disub-kulturkan untuk memperbanyak jumlah spora yang terbentuk. Teknik subkultur dilakukan dengan cara menanam langsung spora dari pot-pot plastic spora tunggal ke dalam pot-pot plastik kecil yang telah diisi zeolit sepertiga volume pot, selanjutnya pot diisi zeolit sampai penuh. Kultur-kultur ini dipelihara di rumah kaca sampai berumur kurang lebih 4 bulan. Selama kegiatan pemeliharaan dilakukan penyiraman dan pemberian larutan hara Hyponex merah (25-5-20) dengan konsenterasi $1 \mathrm{~g} / 21$ air sebanyak $20 \mathrm{ml}$ setiap pot yang dilakukan setiap minggu. Hasil pemanenan kultur digunakan untuk uji keefektifan terhadap bibit jarak pagar pada percobaan selanjutnya.

\section{HASIL DAN PEMBAHASAN}

Hasil

Setiap jenis tanah mengandung jumlah propagul infektif yang berbeda, yaitu di tanah asal ekosistem kebun sebanyak 1117 organisme/g tanah, sedangkan di tanah asal ekosistem alami sebanyak 711 organisme/g tanah. Jumlah propagul infektif yang tertinggi diperoleh pada tanah ekosistem kebun yang lebih beranekaragam jenis tanamannya. Kepadatan spora juga berbeda untuk setiap tanah dari ekosistem yang berbeda. Hal ini terbukti bahwa dengan hasil trapping 
per $50 \mathrm{~g}$ contoh tanah untuk setiap tipe ekosistem menghasilkan jumlah spora yang berbeda, dimana jumlah spora terbanyak adalah di tanah Inceptisol pada ekosistem kebun (130 spora), dan jumlah spora dari tanah Inceptisol ekosistem alami (82 spora). Kepadatan spora sebelum dilakukan trapping hanya 1- 8 spora per $50 \mathrm{~g}$ tanah setiap jenis ekosistem tanah.

Hasil identifikasi spora dari dua tipe ekosistem yang berbeda menunjukkan bahwa dari ekosistem kebun terdapat 7 tipe spora, 3 tipe dari genus Glomus dan 4 tipe dari Acaulospora (Tabel 1), sedangkan dari ekosistem bukan kebun (tanah alami) diperoleh 4 tipe yang semuanya termasuk genus Glomus (Tabel 2). Hasil kultur spora tunggal menunjukkan bahwa hanya spora tipe Glomus sp-1p dan Acaulospora sp-1p yang berhasil hidup, sedangkan lainnya mati.

Berdasarkan kultur spora tunggal didapatkan bahwa terdapat penurunan macam dari masing-masing jenis spora, atau dengan kata lain tidak semua macam spora yang dikulturkan mampu tumbuh dan berkembang. Hasil identifikasi menunjukkan bahwa ternyata hanya terdapat 2 jenis spora yaitu; Glomus sp-1p dan Acaulospora sp-1p. Pada Tabel 2 tampak bahwa jumlah spora jenis Glomus sp-1p lebih banyak dibandingkan dengan jumlah spora jenis Acaulospora sp-1p.

\section{Pembahasan}

Jenis fungi mikoriza arbuskular (FMA) indigeneous asal daerah pengembangan jarak di Desa Poboya Sulawesi Tengah terdapat perbedaan berdasarkan pengamatan pada tanah asal ekosistem kebun dan tanah asal ekosistem alami. Perbedaan jenis dan jumlah/kepadatan FMA antara ekosistem kebun dan alami disebabkan oleh keragaman tanaman dan kondisi lingkungan. Tanaman sebagai inang FMA masing-masing memiliki eksudat akar. Akibatnya semakin banyak jenis tanaman inang, semakin besar kemungkinan terdapat keanekaragaman jenis mikoriza. Menurut Basrudin (2005), kolonisasi dan pembentukan spora FMA dipengaruhi oleh masing-masing eksudat akar tanaman inang. Faktor lain yang juga mempengaruhi pembentukan spora adalah pertumbuhan tanaman inang. Pertumbuhan tanaman jarak pagar yang tumbuh di ekosistem kebun, lebih baik dibandingkan dengan tanaman jarak pagar yang tumbuh di ekosistem alami. Hal ini disebabkan karena tanaman jarak pagar yang tumbuh di kebun, terpelihara dengan baik dan di tanam secara tumpangsari dengan tanaman legum seperti kacang tanah.

Pertumbuhan tanaman yang baik mempunyai fotosintat yang lebih banyak, sehingga memiliki karbon yang dapat digunakan oleh mikoriza, karena mikoriza membutuhkan karbon untuk hidupnya. Dengan demikian maka tanaman yang pertumbuhannya baik memungkinkan untuk bersimbiosis dengan mikoriza dengan jumlah maupun jenis lebih banyak.

Kepadatan spora juga mempunyai perbedaan pada setiap asal tanah yang berbeda penggunaannya (ekosistem kebun dan ekosistem alami). Adanya spesies FMA pada ekosistem kebun dan ekosistem alami dijelaskan pada Tabel 1 dan 2. Kepadatan spora alami sebelum trapping pada setiap jenis asal tanah (ekosistem kebun dan ekosistem alami) hanya ditemukan 1-8 spora/50 g tanah. Hasil ini lebih rendah dibandingkan hasil penelitian Widiastuti (2004) yang mendapatkan 3-103 spora/100 g tanah pada daerah perakaran kelapa sawit. Rendahnya kepadatan spora alami pada rizosfer tanaman jarak pagar ini kemungkinan pada saat 
mengambil contoh tanah, FMA belum bersporulasi, jadi pada contoh tanah tersebut lebih banyak mengandung yang lain seperti hifa (hifa eksternal).

Tabel 1. Jenis spora hasil isolasi dari ekosistem kebun yang ditanami jarak pagar di Desa Poboya Kota Palu Sulawesi Tengah

\begin{tabular}{|c|c|c|}
\hline No. & Tipe Spora & Karakteristik morfologi (pembesaran 400 kali) \\
\hline & $s p-1 p$ & \\
\hline 1. & & $\begin{array}{l}\text { Spora berbentuk bulat, berwarna merah kecoklatan, } \\
\text { permukaan halus, mempunyai hypha perekat (hyphal } \\
\text { attachment) berbentuk lurus dan ujung berbengkok. }\end{array}$ \\
\hline
\end{tabular}

2.

\section{Glomus sp-3p}

3.

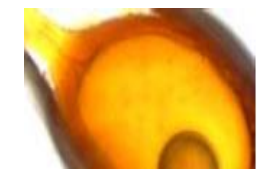

Spora berbentuk bulat, berwarna kuning kecoklatan, permukaan halus, dindingnya berwarna coklat mengkilat
4.

$$
\text { Acaulospora } s p-1 p
$$

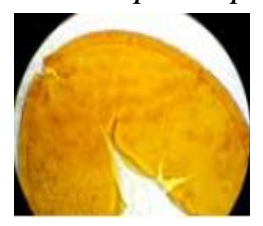

\section{Acaulospora sp-2p}

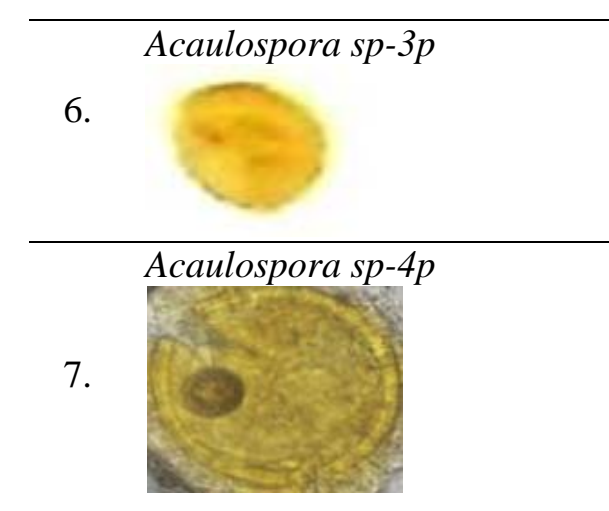

Spora berbentuk bulat agak lonjong, berwarna kuning, permukaan spora agak kasar seperti kulit jeruk. Pada bagian atas dan bawah terdapat lobang bekas terlepasnya arnamennya.

Spora berbentuk bulat, berwarna kuning, permukaan spora agak kasar dan membentuk seperti kulit jeruk. Pada bagian atas dan bawah terdapat lobang bekas terlepasnya ornamennya.

Spora berbentuk bulat, berwarna kuning, permukaan spora agak kasar dan membentuk seperti kulit jeruk. Pada bagian atas dan bawah terdapat lobang bekas terlepasnya ornamennya.

Spora berbentuk bulat, berwarna kuning, permukaan spora agak kasar dan membentuk seperti kulit jeruk. Pada bagian atas dan bawah terdapat lobang bekas terlepasnya ornamennya. 
Tabel 2. Jenis spora hasil isolasi dari ekosistem alami yang di tanami jarak pagar di Desa Poboya Kota Palu Sulawesi Tengah

\begin{tabular}{lll}
\hline No. Tipe Spora & Karakteristik morfologi (pembesaran 400 kali) \\
\hline Glomus $s p-1 b$ & $\begin{array}{l}\text { Spora berbentuk bulat, berwarna merah kecoklatan, } \\
\text { permukaan halus, mempunyai hyphal attachment berbentuk } \\
\text { lurus dan ujung berbengkok }\end{array}$ \\
\hline Glomus $s p-2 b$ & $\begin{array}{l}\text { Spora berbentuk bulat, berwarna kuning kecoklatan, } \\
\text { permukaan halus, mempunyai hyphal attachment berbentuk } \\
\text { lurus }\end{array}$ \\
\hline Glomus $s p-3 b$ & $\begin{array}{l}\text { Spora berbentuk bulat, berwarna kuning kecoklatan, } \\
\text { permukaan agak kasar, mempunyai hyphal attachment } \\
\text { berbentuk lurus }\end{array}$ \\
\hline Glomus $s p-4 b$ & $\begin{array}{l}\text { Spora berbentuk bulat, berwarna kuning kecoklatan, warna } \\
\text { bagian dalam lebih muda, } \\
\text { permukaan halus, mempunyai hyphal attachment berbentuk } \\
\text { lurus }\end{array}$ \\
\hline
\end{tabular}

Hal tersebut didukung oleh terjadinya peningkatan kepadatan spora ketika dilakukan pemerangkapan spora dengan menggunakan tanaman inang Pueraria javanica di rumah kaca. Kepadatan spora ekosistem kebun meningkat menjadi 130 spora/50 g tanah, sedangkan ekosistem alami menjadi 82 spora/50 g tanah. Hal ini sesuai dengan hasil penelitian Kartika (2006) bahwa sporalisasi dipengaruhi oleh musim pada waktu pengambilan sampel tanah.

Jumlah propagul di setiap rizosfer dari asal tanah yang berbeda menghasilkan jumlah propagul berbeda. Hal ini sesuai dengan tanah rizosfer asal ekosistem kebun (1117 organisme/g tanah) lebih baik dibandingkan dengan propagul asal tanah rizosfer ekosistem alami (711 organisme/g tanah). Bervariasinya jumlah propagul dan kepadatan spora di antara contoh tanah kemungkinan karena perbedaan lingkungan asal tanah, sehingga tanah tersebut mempunyai perbedaan hara tanaman, cahaya, dan cara pengelolaan tanah. Jumlah spora dan propagul infektif total dari ekosistem kebun ternyata lebih banyak dibanding propagul infektif dari ekosistem bukan kebun. Hal ini disebabkan, karena jumlah spora dan propagul infektif total juga dipengaruhi oleh jumlah dari jenis FMA yang mengkolonisasi tanaman inang. Semakin banyak jenis FMA yang bersimbiosis dengan tanaman, maka jumlah spora juga akan lebih banyak. Selain itu, tanah dari ekosistem alami tidak memiliki keanekaragaman tanaman (hanya ditumbuhi tanaman jarak pagar), sedangkan tanah dari ekosistem kebun memiliki 
keanekaragaman tanaman yang lebih banyak (jagung, ubi kayu, dan lain-lain). Hasil tersebut sesuai dengan hasil penelitian Kartika (2006) yang menunjukkan bahwa jumlah spora FMA pada suatu jenis tanah ditentukan oleh perbedaan lingkungan, musim waktu pengambilan contoh tanah, jenis tanaman inang, dan adanya tanaman lain pada lokasi pengambilan tanah sampel.

Berdasarkan hasil dan pembahasan di atas, maka untuk mendapatkan jumlah spora yang banyak dapat diisolasi dari daerah perakaran tanaman yang ditanam secara tumpangsari (perakaran tanaman yang beragam). Selain juga perlu diperhatikan keragaan tanaman inang dan waktu atau musim pengambilan sampel tanah.

\section{KESIMPULAN}

Jumlah propagul infektif Fungi Mikoriza Arbuskular ditanah yang berasal dari ekosistem kebun lebih besar (1117 mikrooganisme/g tanah) dibandingkan dengan jumlah propagul infektif Fungi Mikoriza Arbuskular dari ekosistem alami (711 mikroorganisme/g tanah). Jumlah spora hasil trapping tanah yang berasal dari ekosistem kebun lebih besar dibandingkan dengan dari ekosistem alami. Fungi Mikoriza Arbuskular di kawasan pengembangan tanaman jarak di Poboya, Kota Palu, Sulawesi Tengah terdapat 11 jenis Fungi Mikoriza Arbuskular namun hanya 2 yang berhasil dikulturkan yaitu; Glomus sp- 1p dan Acaulospora sp-1p. Fungi mikoriza arbuskular di daerah pengembangan tanaman jarak pagar di Poboya, Kota Palu, Sulawesi Tengah didominasi oleh Glomus sp.

\section{DAFTAR PUSTAKA}

Basrudin. 2005. Pengaruh inang, media tumbuh dan trigger terhadap peningkatan kualitas inokulum cendawan Mikoriza Arbuskular. [Thesis]. Bogor: Sekolah Pascasarjana, Instiut Pertanian Bogor.

Brundrett, MC., Bougherr, N., Dells, B., Grove, T., Malajczuk, N. 1996. Working with mycorrhizal in forestry and agriculture. ACIAR. Peter Lynch (Ed.) Pirie Printers Canberra. Australia.

Kartika, E. 2006. Tanggap pertumbuhan, serapan hara dan karakter morfologi terhadap cekaman kekeringan pada bibit kelapa sawit yang bersimbiosis dengan CMA. [Disertasi]. Bogor: Sekolah Pasca Sarjana, Institut Pertanian Bogor.

Kormanik, PP., Mc Graw, AC. 1982. Quantification of vesicular-arbuscular mycorrhizae in plant root. In. Schenck, NC. (Ed). Methods and principles of mycorrhizae research. The American Phytop. Soc. 46: 37-45.

Kramadibrata, K., Hedger, JN. 1990. A New Species of Acaulospora associated with cocoa in Java and Bali (Indonesia). Mycotaxon 37: 73-74.

Lee, KJ., Lee, KH., Tamolang-Castillo, E., Budi, SW. 2009. Biodiversity, spore density and root colonization of arbuscular mycorrhizal fungi at expressway cut-slopes in Korea. Jour Korean for Soc: 98(5): 539-547.

Pacioni, G. 1992. Wet sieving and decanting techniques for the extraction of spores of VA mycorrhyzal fungi. In. Norris JR, Read and Varma (Fds). Methods in Microbiology, Vol 24, Academic Press Inc, San Diego. p: 317-322. 
Potter, WM. 1979. The 'Most Probable Number' method for enumerating infective propagules of vesicular arbuscular mycorrhizal fungi in soil. Aus. J. Soil. Res. 17(3): 515-519.

Santoso, BB. 2009. Karakterisasi Morfo-Ekotipe dan Kajian beberapa Aspek Agronomi Jarak Pagar (Jatropha curcas L.) di Nusa Tenggara Barat. [Disertasi]. Bogor: Sekolah Pasca Sarjana, Institut Pertanian Bogor.

Schenck, NC, Perez Y. 1990. Manual for The Identification of VA Mycorrhizal Fungi. 3 rd ed. Synergistic Publication. Gainesville, Florida

Sieverding, E. 1991. Vesicular arbuscular mycorhiza management in tropical agroecosystem. Eschborn: Deutsche GTZ GmbH.

Sieverding, E., Oehl 2006. Revision of Entrophospora and description of Kuklospora and Intraspora, two new genera in the arbuscular mycoorhyzal Glomero-mycetes. Angewandite. Botanik 80 (1): 69-81

Wibisono, S.H. 2009. Pemanfaatan Mycorrhizal Helper Bacteria (MHBs) dan Fungi Mikoriza Arbuskular (FMA) untuk meningkatkan kualitas semai Gmelina (Gmelina arborea Roxb). [Thesis]. Bogor: Sekolah Pasca Sarjana, Institut Pertanian Bogor.

Widiastuti, H. 2004. Biologi interaksi cendawan Mikoriza Arbuskular kelapa sawit pada tanah masam sebagai dasar pengembangan teknologi aplikasi dini. [Disertasi]. Bogor: Sekolah Pascasarjana, Institut Pertanian Bogor.

Wiesenhutter, J. 2003. Use of the Physic Nut (Jatropha curcas Linn) to combat desertification and reduce poverty. Convention Project to combat Deserfication - Deutsche Gesellschaft fur Technische Zusammenarbeit (GTZ) GmbH.. 